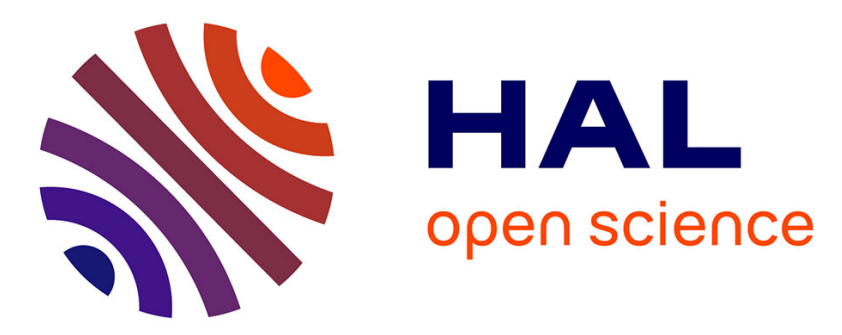

\title{
Assessing freshwater resources in coastal karstic aquifer using a lumped model: the Port-Miou brackish spring (SE France)
}

\author{
Bruno Arfib, Jean-Baptiste Charlier
}

\section{To cite this version:}

Bruno Arfib, Jean-Baptiste Charlier. Assessing freshwater resources in coastal karstic aquifer using a lumped model: the Port-Miou brackish spring (SE France). Bartolomé Andreo et al. Hydrogeological and Environmental Investigations in Karst Systems, 1, Springer-Verlag Berlin Heidelberg, pp.313-321, 2015, Environmental Earth Sciences, 10.1007/978-3-642-17435-3_35 . hal-01164253

\section{HAL Id: hal-01164253 \\ https://hal.science/hal-01164253}

Submitted on 27 May 2021

HAL is a multi-disciplinary open access archive for the deposit and dissemination of scientific research documents, whether they are published or not. The documents may come from teaching and research institutions in France or abroad, or from public or private research centers.
L'archive ouverte pluridisciplinaire HAL, est destinée au dépôt et à la diffusion de documents scientifiques de niveau recherche, publiés ou non, émanant des établissements d'enseignement et de recherche français ou étrangers, des laboratoires publics ou privés. 


\title{
Assessing Freshwater Resources in Coastal Karstic Aquifer Using a Lumped Model: The Port-Miou Brackish Spring (SE France)
}

\author{
B. Arfib and J.-B. Charlier
}

\begin{abstract}
Freshwater resources in coastal aquifers are restricted by seawater intrusion. Studying brackish spring can be an appropriate approach to assess this saline intrusion and to elaborate a conceptual model of the karst aquifer. The aim of this study is to model the hydrogeological flows and the salinity of a brackish spring using a lumped numerical model (Rainfall-Discharge-Salinity), and to quantify the freshwater discharge available. The model is based on a classical karst model composed of connected reservoirs representing the main storage elements of the karst aquifer, which can be deduced from the analysis of discharge and salinity recorded time series. The model was successfully applied on the Port-Miou spring $\left(400 \mathrm{~km}^{2}\right)$, in SE France, which is one of the main submarine springs around the Mediterranean Sea. Four reservoirs were used to model spring discharge and salinity: a SOIL reservoir feeding a DEEP brackish reservoir impacted by seawater intrusion, and two FAST and SLOW reservoirs representing the shallower freshwater resource. We showed that the spring water is always brackish more or less diluted by freshwater during flood events. These results improved the conceptual hydrogeological model of the Port-Miou spring and showed the effectiveness of lumped models to simulate discharge and salinity in coastal karst aquifers.
\end{abstract}

\section{Introduction}

Coastal karstic aquifers may represent important groundwater resources. Exploitation of such aquifer type requires firstly an evaluation of available freshwater. Secondly, withdrawal must be done with a special attention to the saline intrusion processes. Classical scheme of seawater intrusion can be viewed as a more or less

B. Arfib $(\bowtie)$

Aix-Marseille University, CEREGE, Case 67, 3 Place Victor Hugo, 13003 Marseille, France e-mail: arfib@cerege.fr

J.-B. Charlier

BRGM, 1039 Rue de Pinville, 34000 Montpellier, France

B. Andreo et al. (eds.), Hydrogeological and Environmental Investigations

in Karst Systems, Environmental Earth Sciences 1,

DOI 10.1007/978-3-642-17435-3_35 
thick transition zone between fresh and salt water. But this simplified view cannot explain the occurrence of large brackish submarine groundwater discharge (SGD) to the ocean through karstic springs. Saline intrusion distribution in karst aquifer appears more complex compared to porous aquifer, due to the heterogeneity of karst media. Many authors (e.g., Stringfield and Legrand 1971; Arfib et al. 2007; Fleury et al. 2007) have pointed out that submarine karstic springs are connected to preferential flow below the sea level within karst conduits.

The salinity of such springs may be highly variable in time, and is usually related to discharge variations. Thus, in order to assess freshwater resources, a modeling approach is needed, which allows both discharge and salinity to be simulated. Conceptual or reservoir models (frequently called Rainfall-Discharge models) can be used to test hypotheses in order to understand the main hydrogeological processes (e.g., Hartmann et al. 2012). Mixing models can be combined with Reservoir models to simulate discharge as well as chemical variations of spring water (Charlier et al. 2012).

In this setting, the aim of this study is (1) to develop a conceptual model of saline intrusion within a coastal karstic aquifer, and (2) to assess freshwater resources in the aquifer, modeling both discharge and salinity with a reservoirs model. The study site is the Port-Miou spring in south France, which is a large submarine spring having a mean annual discharge of around $7 \mathrm{~m}^{3} \cdot \mathrm{s}^{-1}$.

\section{Study Site}

The Port-Miou aquifer is located in south-east of France (Fig. 1), along the Mediterranean Sea, in a carbonate environment (Jurassic and Cretaceous limestone, dolostone, and mixed siliciclastic-carbonate rocks). Two main submarine springs, Port-Miou and Bestouan, drain the aquifer to the sea in the bay of Cassis. Port-Miou is one of the main coastal karst springs of Europe (Tulipano et al. 2005; Custodio 2010). The recharge area extends on $400 \mathrm{~km}^{2}$, mainly over natural landscape made of hills and karst plateau and polje (Cavalera 2007). The climate is Mediterranean given the mean annual rainfall ranging between 500 and 1,000 mm with storm events of high intensities (up to $100 \mathrm{~mm}$ per day), and drought during the summer season.

The spring outlet has been explored by cave-divers. They discovered a huge saturated karst conduit developed more than $2 \mathrm{~km}$ inland (Fig. 1), with a diameter reaching $20 \mathrm{~m}$. The exploration ended at $223 \mathrm{~m}$ deep below the sea level, in a karstic shaft (Meniscus 2013). One kilometer eastward, the submarine spring of Bestouan gives access to a $3 \mathrm{~km}$ long saturated karst conduit.

In the 1970, a submarine underground dam has been built in the saturated karst conduit of Port-Miou at $500 \mathrm{~m}$ upstream the spring. This dam stopped the seawater intrusion in the subhorizontal conduit, and allows measurements of groundwater salinity coming from the aquifer before the mixing zone with seawater at the outlet. This dam is now an in situ Laboratory to study the SGD and its impact on 


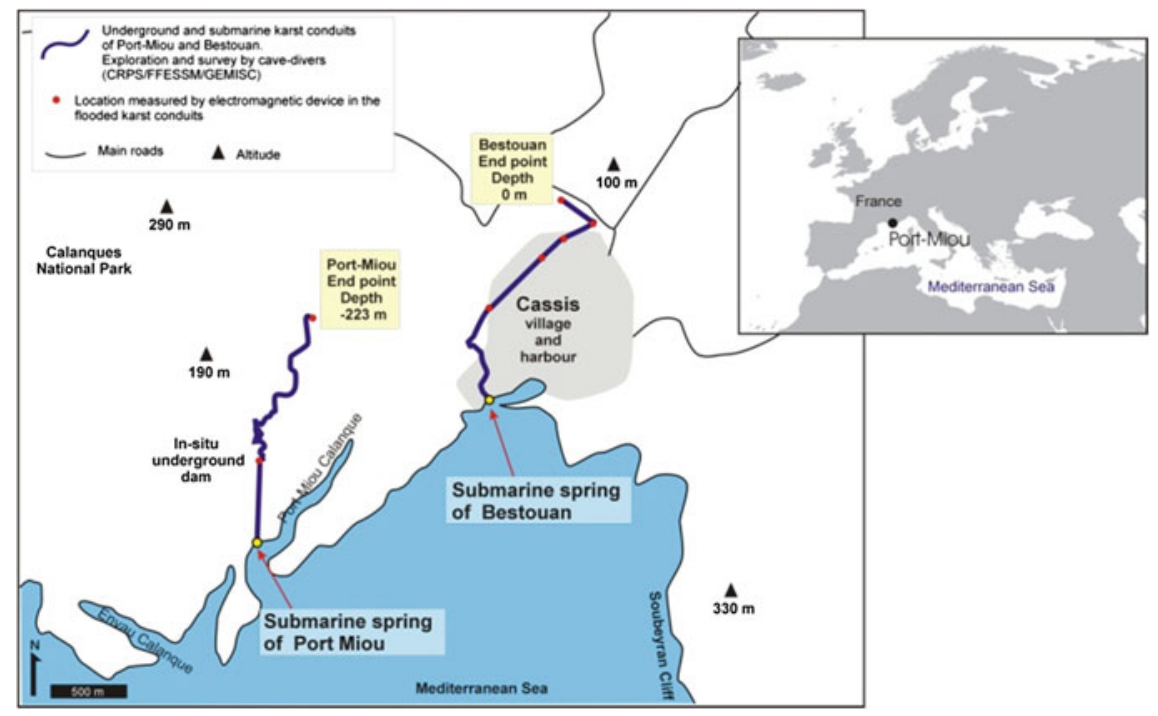

Fig. 1 Location of the Port-Miou case study in France

the sea. Daily rainfall and Potential Evapo-Transpiration (PET) were recorded by METEO France, and spring discharge and salinity were measured in the main conduit upstream the dam.

\section{Conceptual Model of the Coastal Karst Aquifer}

Figure 3 presents 18 months of daily data, showing that the spring is brackish with salinity values ranging from 2 to $12 \mathrm{~kg} / \mathrm{m}^{3}$. During the six main rainfall events, salinity decreases when discharge increases, showing that both parameters are anti-correlated. Even during highest flood events, groundwater remains brackish $\left(2 \mathrm{~kg} / \mathrm{m}^{3}\right)$, polluted by seawater intrusion in depth.

The time series analysis gives insights on the hydrogeological functioning of the aquifer, detailed herein and illustrated in Fig. 2a:

- The groundwater salinity comes from a deeper reservoir, as salinity dilution occurred systematically during flood events. From salinity evolution during recession periods, we may hypothesize that an almost constant salinity inflow occurred with a value of around $14 \mathrm{~kg} / \mathrm{m}^{3}$.

- The aquifer is a typical karst aquifer, with large change in discharge during flood events. The mean response time of a few days shows that a fast infiltration occurs. 
(a)

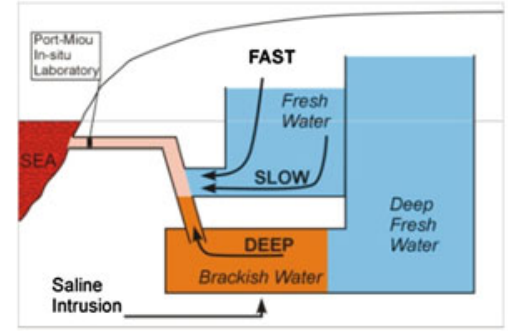

(b)

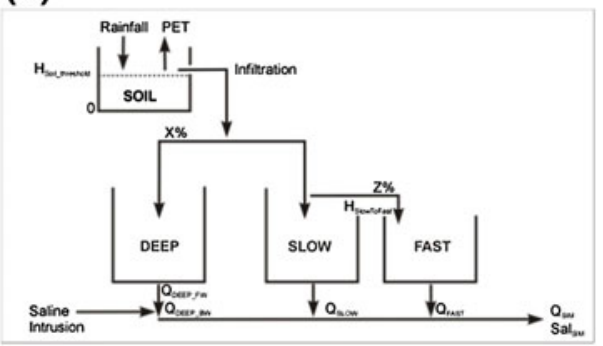

Fig. 2 Conceptual model of the Port-Miou coastal karst aquifer (a), and Structure of the corresponding rainfall-discharge-salinity model (b)

- The groundwater storage appears high according to the long recession curve, showing that a slower component is drained by the aquifer during low flow periods.

Consequently, our conceptual model shows that saline water due to seawater intrusion is mixed in depth with freshwater in a deep brackish water reservoir. A continuous discharge from this deep brackish reservoir is mixed with freshwaters coming from a shallower reservoir, having typical karst response (fast and slow components) to rainfall events.

The conceptual model (Fig. 2a) summarizes water flows from each compartment involved and transfer processes that link them. In order to verify the main hypothesis about the hydrogeological processes highlighted earlier, a modeling approach is presented in the next section. The experimental step was conducted at the aquifer scale, and thus a lumped approach was chosen for the modeling step. The modeling constraints were: (i) to equally represent discharge and salinity fluctuations; (ii) to integrate the three DEEP, SLOW, and FAST reservoirs; and (iii) to accurately simulate the water and mass budget.

\section{Modeling Approach}

\subsection{Model Structure}

Structure and parameters of the conceptual model are presented in Fig. 2b. This model is developed from a modeling approach recently described and tested with good performances on rainfall-discharge-solute data by Charlier et al. (2012). Our model is based on four connected reservoirs. A SOIL reservoir that recharges the aquifer is partitioned into: 
- a DEEP reservoir of brackish water, with low variations of discharge. This reservoir represents the storage function of the aquifer, with a long residence time. Saline intrusion affects this reservoir.

- a SLOW reservoir of fresh water, to represent the storage and the long recession after rainfall events.

- a FAST reservoir of freshwater, to represent the fast infiltration and rapid transfer through the aquifer during high-water event.

Discharge $\mathrm{Q}\left[\mathrm{L}^{3} \cdot \mathrm{T}^{-1}\right]$ at the outlet of each reservoir is calculated as a function of the reservoir stock $\mathrm{H}$ using a linear relation:

$$
\mathrm{Q}=\mathrm{H}_{\mathrm{out}} * \text { Area with } \mathrm{H}_{\mathrm{out}}=\mathrm{H} * \mathrm{kr}
$$

where $\mathrm{kr}\left[T^{-1}\right]$ is a constant characterizing the recession curve of the reservoir. Once $\mathrm{Q}$ are calculated for each reservoir, then salinity is calculated using the following mass balance equations:

$$
\begin{gathered}
\mathrm{Q}_{\text {Spring }} * \mathrm{Sal}_{\text {Spring }}=\mathrm{Q}_{\mathrm{BW}} * \mathrm{Sal}_{\mathrm{BW}}+\mathrm{Q}_{\mathrm{FW}} * \mathrm{Sal}_{\mathrm{FW}} \\
\mathrm{Q}_{\text {Spring }}=\mathrm{Q}_{\mathrm{BW}}+\mathrm{Q}_{\mathrm{FW}}
\end{gathered}
$$

where Sal is the salinity $\left(\mathrm{M} \cdot \mathrm{L}^{-3}\right)$, with subscript Spring for the spring, subscript $\mathrm{BW}$ for brackish water reservoir, and subscript FW for fresh water reservoir.

In the DEEP reservoir, the model assumes that the salinity is constant, equal to $14 \mathrm{~kg} / \mathrm{m}^{3}$ (Sal $\mathrm{BW}_{\mathrm{BW}}$ ). To account for the seawater discharge feeding this reservoir, deep brackish water discharge $\left(\mathrm{Q}_{\mathrm{DeepBW}}\right)$ is calculated from the discharge of freshwater $\left(\mathrm{Q}_{\text {DeepFW }}\right)$ and salinity as follows:

$$
\mathrm{Q}_{\text {DeepBW }}=\mathrm{Q}_{\text {DeepFW }} *\left(\mathrm{Sal}_{\mathrm{SW}} /\left(\mathrm{Sal}_{\mathrm{SW}}-\mathrm{Sal}_{\mathrm{BW}}\right)\right)
$$

where $\mathrm{Sal}_{\mathrm{SW}}$ is the salinity of the seawater (i.e. $38 \mathrm{~kg} / \mathrm{m}^{3}$ ). The percentage of recharge flowing from SOIL to DEEP reservoir is given by the $\mathrm{X}$ parameter. SLOW and FAST partitioning given by the $\mathrm{Y}$ parameter varies from $\mathrm{Y} 1$ to $\mathrm{Y} 2$ according to water level in the SLOW reservoir using a threshold parameter $\left(\mathrm{H}_{\text {Slow/Fast }}\right)$.

\subsection{Parameterization and Calibration Strategy}

The model inputs are the rainfall and PET, and outputs are simulated discharge and salinity, which were compared to the observed ones to test model performances. The model needs a total of nine parameters that may be fixed or optimized. From the results of previous works using recession hydrograph analysis, $\mathrm{kr}_{\mathrm{DEEP}}, \mathrm{kr}_{\mathrm{SLOW}}$, and $\mathrm{kr}_{\mathrm{FAST}}$ and the constant salinity of the DEEP brackish reservoir $\left(\mathrm{Sal}_{\mathrm{BW}}\right)$ were fitted. Finally, five parameters needed to be optimized: $\mathrm{H}_{\text {SOIL_threshold }}, \mathrm{H}_{\text {SLOW/FAST }}$, $\mathrm{X}, \mathrm{Y} 1, \mathrm{Y} 2$. 
Table 1 Calibration values of the model parameters: calibration 1 from Dec. 2010 to Oct. 2011, and calibration 2 from Oct. 2011 to Jun. 2012

\begin{tabular}{l|l|l|l}
\hline Parameter & Signification & Calibration 1 & Calibration 2 \\
\hline $\mathrm{H}_{\text {SOIL_threshold }}$ & $\begin{array}{l}\text { Threshold value to activate recharge from } \\
\text { the soil }\end{array}$ & $34 \mathrm{~mm}$ & $34 \mathrm{~mm}$ \\
\hline $\mathrm{Kr}_{\text {DEEP }}$ & Recession coefficient for the reservoir DEEP & $0.0001 \mathrm{day}^{-1}$ & $0.0001 \mathrm{day}^{-1}$ \\
\hline $\mathrm{Kr}_{\text {SLOW }}$ & $\begin{array}{l}\text { Recession coefficient for the reservoir } \\
\text { SLOW }\end{array}$ & 0.008 day $^{-1}$ & 0.008 day $^{-1}$ \\
\hline $\mathrm{Kr}_{\text {FAST }}$ & Recession coefficient for the reservoir FAST & 0.16 day $^{-1}$ & $0.19 \mathrm{day}^{-1}$ \\
\hline $\mathrm{H}_{\text {SLOW/FAST }}$ & Threshold value in SLOW reservoir & $55 \mathrm{~mm}$ & $55 \mathrm{~mm}$ \\
\hline $\mathrm{X}$ & $\begin{array}{l}\text { Percentage of recharge of the DEEP } \\
\text { reservoir }\end{array}$ & 0.50 & 0.54 \\
\hline $\mathrm{Y} 1$ & $\begin{array}{l}\text { Percentage of recharge of the FAST } \\
\text { reservoir (when H }\end{array}$ & 0.25 & 0.27 \\
\hline $\mathrm{Y} 2$ & $\begin{array}{l}\text { Percentage of recharge of the FAST } \\
\text { reservoir (when } \mathrm{H}_{\text {Slow/Fast }} \text { exceeded) }\end{array}$ & 0.55 & 0.64 \\
\hline Sal & Salinity of the DEEP reservoir & $14 \mathrm{~kg} / \mathrm{m}^{3}$ & $14 \mathrm{~kg} / \mathrm{m}^{3}$ \\
\hline
\end{tabular}

The quality of the simulation for the spring discharge $\mathrm{Q}$ and salinity Sal is evaluated by the Nash-Sutcliffe (NS) efficiency criterion. In order to optimize simulations on low and high values (recessions and flood peak as well as dilutions and brackish water inflows), we compute NS on $\sqrt{ } \mathrm{Q}$ and $\sqrt{ }$ Sal, respectively. Calibration procedure takes also into account the water budget over the calibrated period, optimizing simulations for relative error inferior to $5 \%$ on volume and mass transport. Calibration was carried out manually by a trial-and-error procedure.

\subsection{Application on the Study Site}

The parameterization results of the calibration are given in Table 1 . To avoid the question of the short duration time series, leading to difficult assessment of model performances, a split-sample test (Klemeš 1986) was conducted. This test considers that both subperiod of the whole time series (Dec. 2010 to Oct. 2011, and Oct. 2011 to Jun. 2012) should be used in turn for calibration and validation. Modeling results showed good accuracy on discharge and salinity simulation for calibration and an acceptable performance for validation: NS $\sqrt{ } \mathrm{Q}$ was 0.80 and 0.69 , and NS $\sqrt{ }$ Sal was 0.79 and 0.62 , respectively. The fairly results in validation may come from the flood event distribution. In fact, only one large flood event in November 2011 occured, leading to split the time series in a first subperiod with small events, and a second one with a large event. The range of discharge and salinity is thus different for both subperiods, given more difficulties to optimize model parameters. The water budget is equilibrated in the calibration as well as the validation procedure (Error on volume of 2.5 and $13.6 \%$, and Error on mass of 1.1 


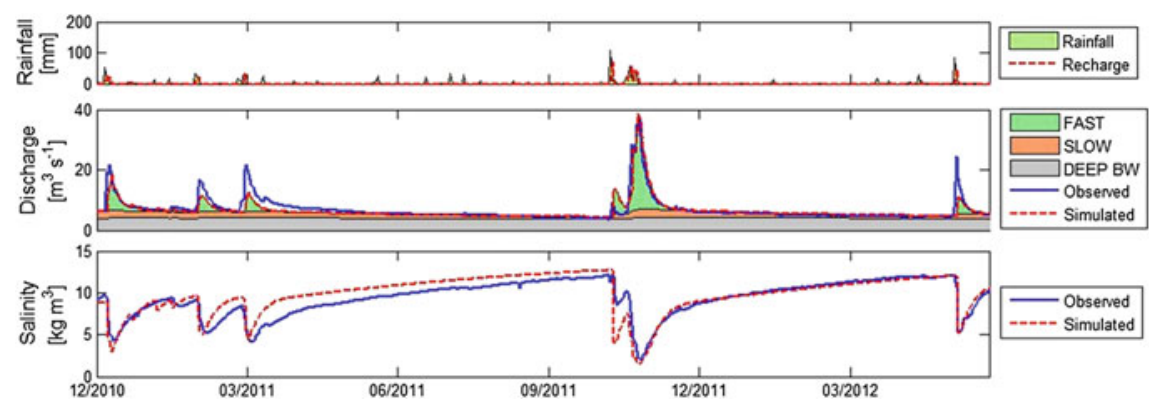

Fig. 3 Simulated and observed data at the Port-Miou spring; calibration was done from Oct. 2011 to Jun. 2012, and validation from Dec. 2010 to Oct. 2011

and $0.9 \%$, for calibration and validation, respectively). Example of simulated recharge, discharge, and salinity are shown in Fig. 3. The general shape of the simulated discharge and salinity plots is well reproduced.

\section{Discussion and Conclusion}

The aim of our study was to develop a conceptual model of saline intrusion within the coastal karstic aquifer of Port-Miou, and to assess freshwater resources in the aquifer using a lumped model. One original aspect of our model is the use of the salinity for the discharge calibration, and conversely. This gives more robustness in the modeling approach, because all parameters influence both discharge and salinity. For instance, $\mathrm{Kr}_{\mathrm{DEEP}}$ and $\mathrm{Kr}_{\text {SLOW }}$ govern discharge recession as well as salinity increase during low water levels. This is mainly the main point of this model, which is relatively parcimonious (nine parameters), when it is used to simulate two independent time series. Advantages of such reservoir model are a simple implementation and an easy adaptation to various case-studies.

We can deduce from the conceptual and numerical models that groundwater flow is spread in several compartments in the aquifer, with their own hydrogeological behavior. These compartments, viewed as reservoirs for modeling purpose, are all connected together to the main karst conduit of the Port-Miou spring.

In the deep part of the aquifer, the freshwater is mixed with saltwater. About $50 \%$ of the effective rainfall (parameter $\mathrm{X}$ ) supplies this deep reservoir (corresponding to $2.5 \mathrm{~m}^{3} / \mathrm{s}$ for the studied period). This aquifer has a strong inertial behavior $\left(k=10^{-4} \mathrm{~d}^{-1}\right)$, which could be coherent with a large storage, with smooth and low changes in hydraulic gradient (there is no karstic-type functioning). The mixing zone should be so wide and the transit time so long that the aquifer provides some brackish water with an almost constant salinity and discharge. This brackish water is drained by the karst conduit of Port-Miou several kilometers upstream the spring, and at least 223 meters below the sea level. This reservoir seems not to be 
affected by high rainfall events. This behavior is very different from the one observed in another main coastal Mediterranean karst, at the Almyros spring of Heraklio (Crete, Greece). In this latter case, Arfib and Marsily (2004) showed that the discharge of seawater to the main karst conduit connected to the outlet changes during high-water events. Furthermore, this discharge can be stopped or reversed (and consequently the spring water became fresh). The Port-Miou model shows that changes in water level in the aquifer, even during high discharge events, can be insufficient to decrease the saline intrusion in order to obtain drinking water.

The Fast and Slow reservoirs can be viewed as the two shallower components of the freshwater flowing through an aquifer not affected by saline intrusion. The Fast reservoir represents the flow through conduits, with a very low storage, but a high transmissivity. This Fast freshwater is the main component of flood events when spring discharge is more or less higher than $8 \mathrm{~m}^{3} / \mathrm{s}$ (Fig. 3). The Slow reservoir simulates the baseflow of the freshwater aquifer. This freshwater aquifer dilutes the brackish water coming from the deep reservoir in the main karst conduit connected to the spring. For the studied period, the fast and slow flows represent on average 1.2 and $1.5 \mathrm{~m}^{3} / \mathrm{s}$ of freshwater at the spring, respectively.

From our results, we can conclude that groundwater is available as freshwater resource in two specific compartments: (1) in the shallower karst aquifer not affected by saline intrusion, and (2) in the deep aquifer, upstream the saline intrusion zone. Further work is still needed to precisely localize the connection zone between both compartments.

Coastal karstic springs are characterized by salinity changes, usually with a decrease in salinity when the discharge increases. In the Mediterranean context, it has been shown that springs can be fresh during high discharge, like in the Almyros of Heraklio case study (Arfib et al. 2007), with the deep saline intrusion stopped due to groundwater height increase. On the contrary, the Port-Miou casestudy shows that the saline intrusion can be almost constant in time, and that the salinity variations are mainly due to dilution of the deep brackish water by a shallower fresh aquifer. Finally, this paper shows that a lumped model is an effective tool to characterize the mechanism of salinity changes.

Acknowledgments This paper is part of the KarstEAU project funded by the "Agence de l'Eau Rhône-Méditerranée-Corse", "Conseil Général du Var", "Conseil Général des Bouches-duRhône" and "Région Provence Alpes Côte d'Azur". We thank N. Mauger (MS Student) who helped in this project. We also thank "Météo France" for the rainfall/ETP data, and the "Conservatoire du Littoral" for the access to the Port-Miou in situ underground laboratory.

\section{References}

Arfib B, de Marsily G (2004) Modeling the salinity of an inland coastal brackish karstic spring with a conduit-matrix model. Water Resour Res 40(11):1-10

Arfib B, de Marsily G, Ganoulis J (2007) Locating the zone of saline intrusion in a coastal karst aquifer using springflow data. Ground Water 45(1):28-35 
Cavalera Thomas (2007) Study of the hydrogeological functioning and the catchment area of the submarine spring of Port-Miou (South-East France). PhD. thesis. University of ProvenceMarseille. 403p.[in French] http://tel.archives-ouvertes.fr/tel-00789232

Charlier JB, Bertrand C, Mudry J (2012) Conceptual hydrogeological model of flow and transport of dissolved organic carbon in a small Jura karst system. J. Hydrol. 460-461:52-64

Custodio E (2010) Coastal aquifers of Europe: an overview. Hydrogeol J 18:269-280

Fleury P, Bakalowicz M, de Marsily G (2007) Submarine springs and coastal karst aquifers: a review. J Hydrol 339:79-92

Hartmann A, Lange J, Vivó Aguado À, Mizyed N, Smiatek G, Kunstmann H (2012) A multimodel approach for improved simulations of future water availability at a large Eastern Mediterranean karst spring. J Hydrol 468-469:130-138

Klemeš V (1986) Operational testing of hydrological simulation models. Hydrol Sci J 31(1):13-24

Meniscus X. (2013) Spring of Port Miou: -223 m on 7 May 2012. Spelunca ${ }^{\circ}{ }^{132}$. 23-27

Stringfield VT, Legrand HE (1971) Effects of karst features on circulation of water in carbonate rocks in coastal areas. J Hydrol 14:139-157

Tulipano L, Fidelibus MD, Panagopoulos A (eds) (2005) COST action 621 Groundwater management of coastal karstic aquifers, p 367 (COST Office) 